\title{
Distribution of FDI across China - Common policies but differing impacts by region
}

\section{John Foster}

Emeritus Fellow, Kingston Business School

Published in Journal of Chinese Economic and Foreign Trade Studies,4(2), 2011, pp $125-138$

Dr M J Foster

Emeritus Fellow

Kingston Business School

Kingston Upon Thames, KT2 7LB, UK

E-mail: foster@kingston.ac.uk

Paper type: Viewpoint/General Review 
Brief Biography:-

M. John Foster is an Emeritus Fellow of the Faculty of Business and Law at Kingston University, in London; before that he was its Associate Dean for a decade. He holds degrees in Mathematics from Warwick (BSc) and Liverpool (MSc) and a $\mathrm{PhD}$ in Corporate Strategy from Oxford Brookes. Current research interests embrace: the effectiveness of strategic planning; evaluation processes for FDI; and business in China and South East Asia. In addition to his administrative position at Kingston, John was the founding director of the Faculty's Asia Business Research Centre (ABRC). He has published in a wide range of journals of international standing, including Strategic Management Journal, Long Range Planning, JORS, Entrepreneurship and Regional Development and Asian Business and Management, on the last named of whose Editorial Board he sits. He has undertaken consulting assignments for major firms in the private sector, the UK's Audit Commission and educational establishments in the UK and overseas. From 1990 to 1993, he was Associate Professor at the City University of Hong Kong 


\title{
Distribution of FDI across China - Common policies but differing impacts by region
}

\author{
Structured Abstract
}

Purpose:

The aim is to illustrate how differing policy instruments linked to FDI into China may have very different impacts. The paper looks at: patterns of FDI across China and other key, emerging nations; FDI patterns across the three declared, developmental regions of the PRC; and the effectiveness of four of the PRC government's policy measures aimed at promoting FDI, and highlights the unexpectedly differing outcomes which can emerge from those incentives.

\section{Design:}

The initial patterns draw on published data of the relevant countries and of the China's three designated development regions. The problem of differing, and unexpected, impacts is examined by means of four mini-cases, drawing on previously published work and featuring a number of locations.

\section{Findings:}

China is near the top of the list of FDI recipients but its relative success compared with other developing economies is more modest. FDI into China is heavily skewed in favour of the richest east region, the poor west being the weakest attractor. The minicases show how the same policy can have very different and sometimes unintended outcomes in different areas. A recurring theme is the existence of common, systemic problems for investors, which may be seen as 'grit' in China's economic system.

\section{Practical implications:}

The PRC government should reflect on what its investment policies may actually deliver as well as their initial intent and to seek to ensure consistent implementation across the country.

\section{Originality:}

The originality of the work lies in the interpretation of existing information: the location of 'hidden truths'.

Keywords: FDI, regions, PRC, incentive policies, outcomes 


\section{Distribution of FDI across China - Common policies but differing impacts by region}

\section{INTRODUCTION}

China, and its more recent, emergent economy rival, India, have become major magnets for FDI in recent years, prior to the sudden dip of the new (2008/9) global recession, which has led to sharply adjusted, global patterns of FDI flows in 2009. China has, over the past 30 years, put in place a range of measures which may be seen as potential incentives to foreign investors, and indeed to domestic investors too, at both national level and 'provincial' level. [The term is shown in parentheses since it is used to include Autonomous Regions and major Municipalities, such as Beijing, which have reporting lines similar to those for provinces.] One of the interesting things to emerge from this context is that some very different outcomes can be observed albeit the nominal incentives may be very similar.

This paper looks first at patterns of FDI across a small set of key, emerging nations, including China and India (section two) and across the three declared, developmental regions of the PRC - east, central and west (section three). The focus of the paper then switches, in the fourth section, to the effectiveness of and varied impacts across regions of attempted, governmental measures. Four different policy measures are examined in turn: viz, creation of specialist zones; establishment of wider geographic, 'development' regions; the effectiveness of Science and Technology Industry Parks (STIPs) as technology transfer agents; and the He Xie or harmony policy in the eleventh five year plan. In section five, we examine the kind of systemic problems commonly found in the PRC in the governance frameworks which apply to 
businesses, both design problems, such as weakly drafted legislation, and operationally observable issues which may have some element of cultural rootedness.

\section{FDI TRENDS GLOBALLY AND IN BIC}

Table 1 below shows the strong upward trend in global FDI over the six year period prior to 2009. Interestingly, the developing economies' FDI receipts grew less quickly than the world's and hence by extension even less quickly than developed economy receipts.

Looking at the nominated countries' data separately shows just how volatile flows can be for a country such as the UK - used here as a developed economy benchmark where the financial sector accounts for a significant proportion of the flows. Inflows for China, India and Brazil, three parts of the so-called BRIC, or BIC, all grew strongly in the period 2004 to 2008 but India markedly faster than China. This last point of course reflects the fact that China's modernisation and economic growth began some 13 years or more before India's, starting points being 1978 (the establishment of the 'Open Door Policy') in China and 1991 for India. In the last year, prior to the general slowdown seen in 2009, India came forward most strongly of the troika, unsurprising in the long term picture: they have further to go having come from a low base. Nevertheless, even they looked set to go backwards early in 2009, with the Indian financial press reporting (financial express.com), in February 2009, that the figure booked for that month was less than one third that for the same period in 2008. However, by the end of April, renewed optimism for India was being shown 
with Reuters (24 April 2009) predicting a modest gain to $\$ 40 \mathrm{bn}$ for the period April 2009-March 2010.

Table 1 - Global Inward FDI Flow Trends (in \$bn)

\begin{tabular}{|l|c|r|r|r|r|c|}
\hline Year & $\mathbf{2 0 0 3}$ & $\mathbf{2 0 0 4}$ & $\mathbf{2 0 0 5}$ & $\mathbf{2 0 0 6}$ & $\mathbf{2 0 0 7}$ & $\mathbf{2 0 0 8}$ \\
\hline World & 561.1 & 717.7 & 958.7 & 1411 & 1833.3 & 1449.1 \\
\hline $\begin{array}{l}\text { Developing } \\
\text { Economies }\end{array}$ & 180.1 & 283.6 & 316.4 & 413 & 499.8 & 519.8 \\
\hline & $\begin{array}{l}\text { Average } \\
\mathbf{1 9 9 0 / 2 0 0 0}\end{array}$ & $\mathbf{2 0 0 4}$ & $\mathbf{2 0 0 5}$ & $\mathbf{2 0 0 6}$ & $\mathbf{2 0 0 7}$ & $\mathbf{2 0 0 8}$ \\
\hline UK & 40.3 & 56.0 & 177.9 & 148.2 & 224.0 & 109.4 \\
\hline Brazil & 12.0 & 18.1 & 15.1 & 18.8 & 34.6 & 41.7 \\
\hline India & 1.7 & 5.8 & 7.6 & 19.7 & 23.0 & 36.7 \\
\hline China & 30.1 & 60.6 & 72.4 & 72.7 & 83.5 & 92.4 \\
\hline
\end{tabular}

Source: Created by the author using data from WIRs, UNCTAD; the data released by mid-2009 are as shown; but in the final 2009 WIR the global figure had become \$1697.4bn and the developing countries figure $\$ 620.7 \mathrm{bn}$

UNCTAD meanwhile, in a press release of $19^{\text {th }}$ January 2009, UNCTAD (2009), noted the 21 percent fall globally in FDI flows in 2008 (as shown in the first data row of Table 1 but, using the revised datum in the footnote, the fall is measured at a more modest 7.4 percent) and predicted worse would ensue in 2009. All of this is of course bad news for the global economy generally but most especially for countries such as China, and probably India too, where the inflow of FDI has been a key driver of growth, and hence modernization, in the country over the past decade, see e.g. Foster and Song (2009). [More generally, a recent issue of World Economy (2006) focused on the issue of which of FDI and GDP actually drives or causes the other in developing economies. Evidence presented suggests that, in line with the findings of Foster and Song, the major linkage is that FDI causes growth in GDP, see the papers by Chowdhury and Mavrotas, pp.9-19, and Hansen and Rand, pp.21-41.] China, and India, should be able to continue to grow their economies, even with weaker FDI 
inflows, not least because of the inherent, untapped domestic economy delivered by prior cumulative growth, and in China's case huge, financial reserves, but the process will be slower. This is precisely what the overall picture has been in India, as compared to China, post 1991. However, as Smith (2008, p92) writes: "For some [Indians], the slow but steady approach was preferable; the Indian elephant may have chosen to travel at a gentler pace than its great rival, China, but the race would be a long one, and who [is] to say that India 's [pace will] not be more sustainable in the long run."

Smith later predicts (p229) that, given various assumptions, China may have a per capita National Income around two thirds of current US levels by 2050, with Indians in turn enjoying a level two thirds that of their Chinese brothers. Seen from one angle, a disappointment 40 years on from now but the gap will have closed markedly if those projections are right. As Table 2 below shows, current (2008) levels of GNI per capita for Indians are less than half (46 percent) the per capita income of the Chinese. Arguably the more important statistic, if correct however, will be the Chinese having $67 \%$ of the per capita income of the Americans and Indians $45 \%$ of that US income. These numbers compare very favourably with the current ordered pair of just $(4.5 \%$, $1.8 \%)$.

Table 2 also shows clearly where India and China are on the modernization curve for which the percentage of urban dwellers is a fair proxy. Brazil at this point in time still provides a more tangible, immediate target for India and China than developed countries such as the UK or the USA, both in terms of income per capita (Table 2) 
and FDI per capita (Table 3), which will be one of the twin motors of future growth in these countries.

Table 2 - Country Biodata: BIC and Comparators (2008)

\begin{tabular}{|l|l|l|l|c|l|}
\hline Country & $\begin{array}{l}\text { Population } \\
(\mathbf{m})\end{array}$ & $\begin{array}{l}\text { Life Exptcy } \\
(\mathbf{y r s})\end{array}$ & Urban \% & GNI (\$bn) & $\begin{array}{l}\text { GNI/Cap } \\
(\mathbf{\$ k})\end{array}$ \\
\hline Brazil & 190 & 72.24 & 84 & 892.6 & 4.7 \\
\hline China & 1322 & 72.88 & 40.5 & 2621 & 2.0 \\
\hline India & 1130 & 68.59 & 28.7 & 909.1 & 0.82 \\
\hline Thailand & 65 & 72.55 & 33 & 193.7 & 3.05 \\
\hline UK & 60.8 & 78.7 & 90 & 2455.7 & 40.6 \\
\hline USA & 301 & 78 & 81 & 13386.9 & 44.7 \\
\hline
\end{tabular}

Source: Created by the author using data from Whitaker's Almanack, 2009

Table 3 - Per Capita Inbound FDI for BIC and the UK (\$ per capita)

\begin{tabular}{|l|c|c|c|c|c|}
\hline $\begin{array}{c}\text { \Year } \\
\text { Country }\end{array}$ & $\mathbf{2 0 0 4}$ & $\mathbf{2 0 0 5}$ & $\mathbf{2 0 0 6}$ & $\mathbf{2 0 0 7}$ & $\mathbf{2 0 0 8}$ \\
\hline UK & 921 & 2926 & 2438 & 3684 & 1799 \\
\hline Brazil & 95.2 & 79.5 & 98.9 & 182.1 & 219.4 \\
\hline India & 5.2 & 6.7 & 17.4 & 20.4 & 32.5 \\
\hline China & 45.8 & 54.8 & 55.0 & 63.1 & 69.6 \\
\hline
\end{tabular}

Source: Created by the author using data from WIRs, UNCTAD; Whitaker's Almanack, 2009

We can also see very clearly from Table 3 just how far ahead of China Brazil is in terms of FDI per capita flows, despite China having the clear lead amongst developing economies in aggregate FDI inflows, more than double Brazil's figures throughout the recorded period (see Table 1). Aggregate numbers are important because, once large enough, they allow the development of some sort of scale investments in the chosen country, or area within, but the per capita data illustrate vividly just how far even the more successful developing countries still have to go to achieve their implicit goal of parity of living standards with the 'rich west'. 


\section{PATTERNS OF FDI ACROSS CHINA'S REGIONS}

In 2000, the PRC government confirmed its 'Go West Strategy' recognizing that stability and harmony within China would be initially difficult and progressively harder to maintain if they continued to oversee an increase in national wealth which was very skewed in its distribution, see for example Goodman (2004). The eastern coastal strip in particular, which includes the key cities of Beijing, Shanghai and Guangzhou, as well as the old capital of Nanjing, Tianjin, Shenyang and Hangzhou, has become wealthy and other areas have lagged behind, especially parts of the far west. One could say, with the benefit of hindsight by mid-2009, that the disorder seen in preceding months in Tibet and Xinjiang have been evidence of precisely the kind of events 'Beijing man' feared. To be sure there are political issues in those autonomous regions way beyond the prosaics of the distribution of national income but not getting one's share of the national wealth cake also causes disgruntlement.

There is an official allocation of provinces, autonomous regions and 'province status' (or key) municipalities to three regions (East, Central and West), relative to which 'Go West' is to be understood. In terms of the affluence of the inhabitants, the regions, in order, can be thought of as rich, moderate income and poor. The classification is not entirely true to the country's geography but rather reflects the kind of economic manipulation attempted in the Go West policy. The allocation is:

East: Beijing*, Tianjin*, Hebei, Liaoning, Shanghai*, Jiangsu, Zhejiang, Fujian, Shandong, Guangdong, Hainan 
Central: Shanxi, Jilin, Heilongjiang, Anhui, Jiangxi, Henan, Hubei, Hunan

West: Inner Mongolia, Guangxi, Sichuan, Chongqing*, Guizhou, Yunnan, Shaanxi, Gansu, Qinghai, Ningxia, Xinjiang, Tibet

(* denotes a key municipality)

Table 4 below demonstrates vividly the skew involved in FDI attraction, much more even than the disparity in GDP (/per capita), this despite the fact that Sichuan province and Chongqing municipality lie in the western region. In fact, Sichuan Province and Chongqing Municipality accounted for very nearly half of the realized FDI in the whole Western Region in 2008, up from figures between 30 and 40 percent for all years from 2003 to 2007, showing just how weak the rest of the region was as an FDI-attractor.

Table 4 - Cumulative FDI in the Defined Regions of China to 2008

\begin{tabular}{|l|r|r|r|r|r|r|}
\hline & & US\$bn & & \multicolumn{1}{c|}{ US\$bn } & \\
\hline Region & $\begin{array}{c}\text { No. of } \\
\text { projects } \\
\text { to 2002 }\end{array}$ & Share \% & $\begin{array}{c}\text { Realized } \\
\text { FDI Value } \\
\text { to 2002 }\end{array}$ & Share \% & $\begin{array}{c}\text { RDI Valized } \\
\text { to 2008 }\end{array}$ & Share \% \\
\hline East & 345,054 & $81 \%$ & 385.5 & $86 \%$ & 832.7 & $83 \%$ \\
\hline Central & 49,443 & $12 \%$ & 39.7 & $9 \%$ & 116.4 & $12 \%$ \\
\hline West & 29,699 & $7 \%$ & 22.8 & $5 \%$ & 58.8 & $6 \%$ \\
\hline Total & 424,196 & $100 \%$ & 448.0 & $100 \%$ & 1007.8 & $100 \%$ \\
\hline
\end{tabular}

Source: Created by the author using data from China Statistical Yearbooks and Provincial Statistical Yearbooks (various issues)

The table in Appendix 2, reliability caveat therewith notwithstanding, gives a clear 
elaboration of the picture in Table 4. The East still dominates the PRC's acquisition of FDI although the final two columns show that there has been some slight proportionate movement to the Centre and the West over the last four years data available: but one stresses 'slight'. In that sense, the 'Go West' policy has had limited success thus far, as seen through the FDI-lens. Paradoxically, the even more pronounced skew within the West in 2008, noted above, just may be evidence of some small success in the Go West policy: the success would be the attraction of FDI to the West and the irony (hence paradox) being that it was attracted to one of the already richer bits of that poorer region.

\section{CHINA GROWTH-LINKED POLICIES AND EVIDENTIAL VIGNETTES AT NATIONAL AND REGIONAL LEVELS}

We can identify a number of policies or schemes by means of which it was hoped to boost, develop and grow the Chinese economy since 1978. The first and perhaps most obvious was the very fact of welcoming foreign investment at all post-1978 with the declaration of the Open-Door Policy. As noted before, this has helped to boost the PRC economy but the impact has been heavily skewed in terms of its geographical impact, with the knowledge, and active connivance, of the Beijing government. This in turn raises its own problems, now being addressed somewhat, see the previous section and in what follows.

The remainder of this section looks at a number of policies with both national and provincial focus, to see how the same nominal, central policies may play out with differing effects across a country as vast and diverse as China. 


\section{Creation of Specialist Zones}

One particular policy to aid industrial development has been the designation of various specialised "zones", which helped to create industry (specialist) clusters (see e.g. Porter, 1998 and 2000) and conferred benefits on their tenants. The first and best known were the Special Economic Zones (firstly four: Shenzhen (the 'new Hong Kong in China'), Zhuhai, Shantou - all in Guangdong - and Xiamen (in Fujian), to which a fifth, Hainan, was later added), all located in the South East bar Hainan. In addition, by 1995 there were other zones, including Free Trade Zones (free-ports); coastal, “open cities"; Economic and Trade Development Zones; New/High-Tech Industrial Development Zones (HTIDZs); and finally, the slightly broader reality which is the Pudong New Area, or industrial East Shanghai, see e.g. Pu and Foster (1996)

Typically, these zones provide certain benefits both of infrastructure and tax/customs regime inter alia. SEZs, specifically, benefited from autonomy in regard to investment policy and infrastructure development; import licence exemptions; and tax breaks, see e.g. Tseng and Zebregs (2003). For many years the corporate income tax rate (what we would call corporation tax) for their foreign invested enterprises (FIEs), along with the rate for hi-tech FIEs in HTIDZs, was no more than $15 \%$ compared with the national figure of $33 \%$. Abolition of the $15 \%$ rate had been 'rumoured to be imminent' over almost a decade, but there was finally a change via the PRC Enterprise Income Tax Law (2007), passed on $16^{\text {th }}$ March 2007, to a new, unified national rate of corporation tax of $25 \%$, with effect from $1^{\text {st }}$ January 2008 . However, even then, as Zhao and Yuan (2007) note, there can still be some exemptions, e.g. the SEZs, the Pudong New Area, the Western Development Region and for hi-tech entities so classified, with 'hi-tech' 
undefined!

And within those last two sentences lies one of China's greatest governance issues, which in turn has two aspects. Namely, the 'flexibility' legitimately built in to much regulation, with a consequent, genuine need for interpretation and the exercise of interpretation which may be less than legitimate. This is discussed further in section 5 .

So far so good but are these zones successful at all and similarly so across their geographic distribution? The SEZs have, in the eyes of most, worked to some extent at least, although not uniformly so - Hainan may be thought less successful for example. The success there has been in the SEZs has been in no small measure because of the investments there from Hong Kong and Taiwan. Shenzhen is a dramatic and visible success: it looks pretty much what it was intended to be, a throbbing, new Hong Kong in mainland China. [Although the politics are that Hong Kong is now part of the PRC, its status, along with Macau, as a Special Administrative Region (SAR), with its own different legal system to run until 2047, means that it is effectively 'outside China'. It can be thought of as an overseas colony, which is still an entrepôt with very low tax rates and, crucially top-drawer recognition from the main trading blocs of the world.]

Similarly HTIDZs have had a good measure of success in terms of simply providing a clustering focus for hi-tech industries (although not necessarily in other important respects, see section 4.3) and are to be found in both Nanjing, capital of Jiangsu Province, and Shanghai, the totem head of the Yangtze Delta. Both municipalities are home to many FIEs but, as Foster and Wang (2007) explain, Nanjing was disappointed by its relative lack of success compared to Shanghai and the smaller (but better foreign 
invested) Suzhou: the FDI per capita inflows to the three cities back in 2002 were respectively (\$268, $\$ 375, \$ 830)$. While those in poorer parts of China would probably have been delighted with that flow-rate, Nanjing was starting to actively initiate a debate on how to improve its presence as an FDI-attractor. Foster and Wang identified several potential reasons for Nanjing's relative failure. These included:

- Failure to focus sufficiently on its principal, pillar industries;

- Unwillingness to see its position as part of Greater Shanghai to be a key advantage to be leveraged*;

- Lack of professionalism in its PR; and

- Failure, along with most other parts of China, to deliver genuine transparency for FIEs.

[* It was suggested that this could in part be usefully visualised by using the nested-double diamond they proposed: the nested diamond is illustrated in Appendix 1]

Thus we see that even within successful, or rich, parts of China, the same policies can have differential impacts.

\section{Wider Geographic Regions beyond focussed Zones}

A more recent and geographically more broad-brush, zonal-type policy is exemplified by the creation of the Pan Pearl River Delta (PPRD) Region. The early focus around Guangdong in particular was a function of the political reality of the 1970s and 1980s. The 'Taiwan Issue' was a major problem; the Hong Kong problem, as perceived by Beijing, was in the process of solution but not fully so until 1997; and much of the world, including crucially the USA, was cautious about China and its motives. Against 
this background, with its conduit to the west through Hong Kong, Guangdong was a pragmatic location for a new export oriented growth phase, industrially possible and politically feasible because of Hong Kong's external status as a British Colony and freeport, see Overholt (1993). The PPRD Region was set up under the CEPA (Closer Economic Partnership Arrangement) in July 2003. It is an "economic super-zone", comprising the nine southernmost provinces of the PRC plus its two SARs (Hong Kong and Macau); hence sometimes known also as "9+2". It sought to bring together the already more developed Guangdong, its developed neighbouring SARs and some less developed provinces such as Guizhou, Yunnan and the autonomous region (AR) of Guangxi to provide a mutually self supporting area capable of new growth.

Until the advent of policies such as the creation of PPRD and the establishment of the 'Go West' policy, it could be argued that there had been a tendency for industrial development to be based on a one size for all approach, to modify the well known saying. So the poorer South West part of the South, rather than the rich South East began to get more consideration. Within the far-South West, Guangxi AR is the main geographical feature. It is bigger by area than Guangdong and has 60 percent the population at just under $50 \mathrm{~m}$ but on the economic indicators has barely one-fifth the GDP and FDI of less than 5 percent that of Guangdong. But it is not all bad news. Guangxi is sometimes described as "Facing South East Asia with the Great South West of China Behind", because of its geographic setting, see Foster and Song (2009). It has a border with Vietnam in its south-west quadrant and is close to Hong Kong and Macau, hanging off Guangdong, as they do. In other words it has a strategic location and one whereby this autonomous region could be made into the trading gateway for most of the West region's industrial exports and imports. 
Another benefit is that it is rich in natural resources including: water for hydro-power; oil and gas; minerals (89 varieties); one of the key forest areas in southern China; and, of course, it's hitherto fairly unspoilt sea-side, for details see Song (2004).

With spectacular (internal) landscapes and scenery, good climate, and low pollution, Guangxi has begun to develop as a centre for (mainly internal) tourism and could have external potential with good planning. The autonomous region offers then a prime example of an area which could still be developed but in an eco-friendly fashion. Forests could be managed sustainably; minerals could be extracted in as eco-friendly a fashion as may be technically feasible; and the coastal region could, with sensible planning, be developed in a non-polluting fashion (e.g. only build luxury, beachside hotels in tandem with effluent treatment plants, maintaining the clear blue waters as the advantage they are at present).

In short, PPRD is at once both an example of the differences still visible from the same policy within the southern part of the country and on the other hand an exemplar of the move to try to help the less advantaged areas, in this case by linking them with the success story which is Guangdong with its three SEZs and the two SARs.

\section{Science and Technology Industry Parks - has Technology transferred?}

Science and Technology Industry Parks (STIPs, another name for HTIDZs) and university science parks include in their aims specifically delivering useful applied research and innovation by developing a creative nexus between universities and their adjacent or nearby STIPs, and more generally promoting hi-tech industry. The idea 
like science parks elsewhere, such as in the UK, was basically to set up an area which includes incubator units close to powerful, research-led universities, whereby scientists could interact with entrepreneurs to deliver a new innovatory product, and/or process, stream, or indeed take forward their own ideas and become entrepreneurs in their own right. Because of the concentration of many of the country's leading research universities in Beijing and Shanghai, this means that there are rather more STIPs in those two province status municipalities than elsewhere. But have they worked, has the policy been uniformly effective?

In this case, it is of course clear that many of the new units will be domestic entities but there is no bar in principle to FIEs locating in STIPs and there are examples of this phenomenon, see e.g. Watkins-Mathys and Foster (2006) and Cao (2009).

The short answer to our question is 'only partly' and the main, missing ingredients to make the knowledge transfer work, hence delivering commercialised innovations, are entrepreneurship and management skills. As Watkins-Mathys and Foster (2006) reported: "We found that innovation capability, locational factors such as being located in a regional industry cluster (in or outside STIPS), guanxi and networking opportunities, entrepreneurial skills, including international business experience, as well as access to more financial sources and capital for developing the business are more important than the government's preferential policies. Nevertheless, many of the government's STIPs are located in China's industrial agglomerations, which have been proven to increase export performance and enhance a firm's innovation capability."

During the fieldwork for that research, the authors interviewed entrepreneurs located 
outside as well as inside STIPs. One interviewee who had indeed chosen not to locate in a STIP is quoted as saying: (p267): "More important than having tax incentives and reduced rents is to have a good business idea and a well worked out business plan." Furthermore, the location he had chosen, in Beijing, did not preclude networking with Beijing's universities and recruiting well-qualified interns and graduates from them.

Cao's (2009) more recent work, specifically about SMEs in the IT-software sector, confirms the 'missing link' of entrepreneurial spirit and also highlights the paucity of venture capital in China and the difficulty for SMEs to gain any sort of long-term financing from the traditional banking sector. Thus we could say that the STIP/science park model could work but only if all contextual factors are truly in place. Incentives, tax-breaks for example, while other necessary conditions for success are absent, will not deliver the hoped for outcomes.

\section{Building a 'Harmonious Society'}

Another recent policy of the central government, announced in the eleventh Five-Year Plan in 1998, is the objective 'to build a harmonious society', or to use another phrase to operate a He Xie (or harmony) policy. This is an attempt to deal with the perceived, and indeed real, inter-provincial unfairnesses that the arguably unfettered, headlong drive for quick economic gain left in its wake as the $21^{\text {st }}$ century dawned. As Cao et al (2008) explain, by the close of the $20^{\text {th }}$ century, the new industrial imperative was to upgrade the country's industrial structure to allow the achievement of sustainable development and growth. As part of that, there were measures to, (p279-80), "hasten the introduction and development of High-tech industrial clusters such as biotechnology, microelectronics, semi-conductors and medicine." As this happens or 
would happen on the one hand, what was to be done to assuage the worries of those based in areas with declining clusters, often centred on older technology, dirty industries, e.g. Shanxi with its coal (energy), heavy industries and chemicals, all rooted in its indigenous natural resources?

The problems of places such as Shanxi can crudely be described as a highly focussed 'resource rape' of extractive materials necessary to underpin the first phase of the postMao industrial resurgence. The problem was and is that there was no immediate Plan B in place when things began to tail off somewhat. Not only that, but there had been a brain drain from Shanxi, with the result that one of the key necessities for a more knowledge based, new industrial phase was lacking, viz, large quantities of trained intellectual firepower. While Shanxi produced the coal to deliver power, the Beijing government controlled its price to help make manufacturing industry profitable and able to export. Thus a paradox occurred: the country got rich but the province lagged further and further behind in real income terms. Only post 2003, with new export markets for coal products and sharply increased prices did that income even begin to catch up with the rest of the country and there was little, non-extractive, higher knowledge component development and the brain drain was in flow.

Cao et al (2008) propose that application of so-called He Xie Management Theory could provide the framework for a solution in the case of Shanxi. While He Xie as a phrase may translate broadly as 'harmony', they take the two characters and work with them separately to explain how the theory might help. He can be taken to mean a principle of evolution and Xie can be interpreted as 'design and planning', they say. Thus, if central and local government recognise the need for and then set up effective 
institutional arrangements to coordinate their planning and design (the Xie), those needs can begin to cohere and form a stable basis for change. Such structural change also requires changes in psychological and cultural thinking for both the individual and the society. They suggest that $H e$ is the necessary evolution of the mind-set (or sets!), opening the way to necessary, developmental planning. This may seem, at one level, slightly trite but, if it offers a way for bureaucrats to make changes for good, while saving 'face', it cannot be other than a good thing. This is an example where the tensions between the national and provincial governments in the PRC can be illustrated by the explanatory, 'seven forces', contextual model proposed by Tseng and Foster (2006); regional and national government comprise the sixth and seventh forces in their model.

\section{COMMON PROBLEMS AND CONCLUSION}

We began by comparing China's FDI with that of other key developing countries and the rest of the world. It emerges that although China is a big player in aggregate terms its per capita position is much less strong. Turning to the distribution of that FDI across China the picture is very skewed between the rich East and the rest of the country. The fourth section showed how a single policy or action can have very differing outcomes in its implementation, sometimes understood and sometimes coincidental, including policies specifically aimed at generating growth, for which FDI is one key driver. Finally, we highlight some common problems which are 'annoying grit in the machinery' of business life in China, especially irritating from the perspective of foreign investors perhaps. First there is the issue of 'flexibility' raised earlier, in the first sub-section of the fourth main section. If regulations or laws 
are loosely drafted making interpretation inevitable, it can cause two problems. On the one hand, one may simply get well intentioned differences of opinion: official A thinks this rule/law means $\mathrm{X}$ while official $\mathrm{B}$ thinks it means $\mathrm{Y}$. Both are trying to be honest but the lack of drafting precision means two investors face two different effective rules in two different locations.

On the other hand 'flexibility' can be shorthand for corruption by officials. For example, the young (Chinese) researcher engaged in our Nanjing enquiry, asked the local tax bureau there for a definitive breakdown of the tax regime being applied in the city and its development zones: the official refused a reply. From an outsider's perspective the only possible reason for such refusal could be that there was no consistent tariff in operation for all the wrong reasons. Another example comes from a close, Chinese friend of mine, from Hong Kong, who is a chartered accountant trained in the UK. He told me how he would compute his family firm's PRC tax liability and then go to the tax bureau in Guangdong. The final sum payable was always a matter of negotiation, he reports, even if he showed the official whom he met the calculations he had prepared, faithfully computed in line with the tax regulations. Another word to cover this sort of difficulty is 'transparency', or the lack of it.

Corruption can of course be even more direct, the pay for a permit syndrome: sadly China, like India, is not free of this disease.

Another problem in the transparency mix in China is that regulations can be subject to change without notice. For example, November 2006 saw the promulgation of guidance on so-called 'Regulation 17' concerning supplier-retailer contractual links. 
One of its effects was to say that what had hitherto been lawful and agreed contracts were no longer approved and that foreign investors had to renegotiate their supplier deals on a basis materially more favourable to the local suppliers. How can one sensibly plan for this sort of quixotic regulatory change?

Finally there is the whole issue of IPR. China says it is aware of the problem and is committed to dealing with it. However, the problem persists as one understands it.

What the Chinese government, along with many others, sometimes seem to miss is the point that companies are not naïve: they don't expect to like all regulations (e.g. would we not all like income tax to be 1 percent say but we know it has to be much more!) but they do want: transparency; that policies be applied consistently over time; and honesty. Provinces such as Shanxi might also add pan-country fairness of outcome, given their role in the Deng-era of 'energy skivvies'.

\section{REFERENCES}

Aggarwal, A. (2006), 'Special Economic Zones: Revisiting the policy debate', Economic and Political Weekly, Nov $4^{\text {th }}, 4533-36$.

Cao, J-H. (2009), 'The role of entrepreneurship, in PRC small and medium-sized software firms, in effecting technology transfer from local universities', Unpublished Doctoral Thesis, Kingston Business School. 
Cao, X-W., Xi, Y-M. and Zeng, X.J. (2008), 'Upgrading resource-based regional industrial clusters to innovative clusters: the case of Shanxi Province in China', Asian Business \& Management, 7(3), 277-295.

China Statistical Yearbook, 2002, 2004, 2008

Chowdhury, A. and Mavrotas, G. (2006), 'FDI and growth: what causes what?', World Economy, 29(1), 9-19.

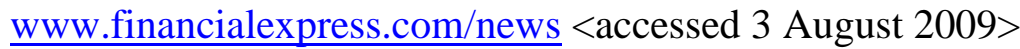

Foster, M.J. and Song, Yin (2009), 'FDI: differential fuel for Guangxi a poorer Chinese region', International Journal of Chinese Culture and Management, 2(4), 367-384.

Foster, M.J. and Wang, Zhuo (2007), 'Nanjing's performance as China's FDI inflows grow', International Journal of Management and Decision Making (Asia Issue), 8(2-4), 426-439.

Goodman, D.S.G. (2004), 'The campaign to "Open up the West": National, provincial and local perspectives', The China Quarterly, 178, 317-334.

Hansen, H. and Rand, J. (2006), 'On the causal links between FDI and growth in developing countries', World Economy, 29(1), 21-41. 
Overholt, W.H. (1993), China the Next Economic Superpower. London: Weidenfeld and Nicolson.

Porter, M.E. (1998), 'Clusters and the new economics of competition', Harvard Business Review, 76(6), 77-90.

Porter, M.E. (2000), 'Location, competition and economic development: local clusters in a global economy', Economic Development Quarterly, 14(1), 15-35.

Pu, Z. and Foster, M.J. (1996), How to do Business in China, Business Paper Series, Kingston Business School.

Reuters Press Release 24 April 2009 <accessed on-line 3 August 2009>

Smith, D. (2008), The Dragon and the Elephant - China, India and the New World Order. London: Profile Books.

Song, Yin (2004), 'Evaluation of Foreign Direct Investments (FDIs) in China: A Case Study of the 'Province' of Guangxi', MA Dissertation, Kingston Business School.

Statistical Yearbooks, 2005-2008, for the 27 Provinces and Autonomous Regions and the 'Province status' Municipalities of Beijing, Chongqing, Shanghai and Tianjin 
Tseng, C.S. and Foster, M.J. (2006), 'A flexible response to Guo Qing: experience of three MNCs entering restricted sectors of the PRC economy', Asian Business \& Management, 5(3), 315-332.

Tseng, W. and Zebregs, H. (2003), 'Foreign direct investment in China: some lessons for other countries', in: Tseng, W. and Rodlauer, M (Eds.), Competing in the Global Economy, Intl. Mon. Fund, 68-88.

UNCTAD (2005), World Investment Report 2004. New York and Geneva: United Nations

UNCTAD (2006), World Investment Report 2005. New York and Geneva: United Nations

UNCTAD (2007), World Investment Report 2006. New York and Geneva: United Nations

UNCTAD (2008), World Investment Report 2007. New York and Geneva: United Nations

UNCTAD (2009), World Investment Report 2008. New York and Geneva: United Nations

UNCTAD (2009), Press Release, $19^{\text {th }}$ Jan 2009/Annex. 
Watkins-Mathys, L. and Foster, M.J. (2006), 'Entrepreneurship: the still missing ingredient in China's STIPs?', Entrepreneurship and Regional Development, 18(3), 249-274.

Whitaker's Almanack, 2009. A\&C Black: London

Zhao, W. and Yuan, L. (2007), 'A unified corporate income tax rate comes to China', China Law \& Practice, April.

<accessed on-line $10^{\text {th }}$ Aug 2009 at: www.chinalawandpractice.com > 


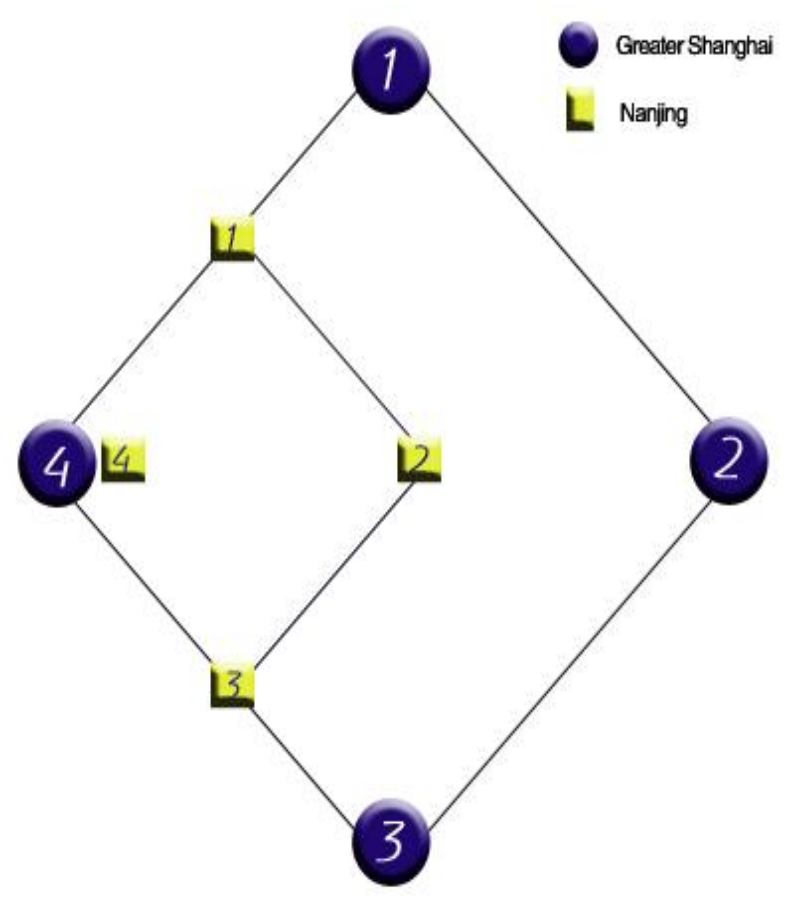

(1) Firm strategy/structure rivalry

(2) Demand conditions

(3) Related and supporting industries

(4) Factor conditions/infrastructure

(all interpreted in terms of the 'host' locations) 


\section{Appendix 2}

Table of Cumulative FDI in the Defined Regions of China to 2008

\begin{tabular}{|c|c|c|c|c|c|c|c|c|}
\hline & US\$bn & & US\$bn & & US\$bn & & US\$bn & \\
\hline Region & $\begin{array}{l}\text { Realized } \\
\text { FDI value } \\
\text { to } 2002\end{array}$ & Share \% & $\begin{array}{l}\text { Realized } \\
\text { FDI value to } \\
2004\end{array}$ & Share \% & $\begin{array}{l}\text { Realized } \\
\text { FDI value to } \\
2008\end{array}$ & Share \% & $\begin{array}{l}\text { Difference } \\
2008 \text { less } \\
2004\end{array}$ & Share \% \\
\hline East & 385.5 & 86 & 482.9 & 86 & 832.7 & 83 & 349.8 & 78 \\
\hline Central & 39.7 & 9 & 52.2 & 9 & 116.4 & 12 & 64.2 & 14 \\
\hline West & 22.8 & 5 & 26.3 & 5 & 58.8 & 6 & 32.5 & 7 \\
\hline Total & 448.0 & 100 & 561.4 & 100 & 1007.8 & 100 & 446.4 & 99 \\
\hline
\end{tabular}

Source: Created by the author: data in this table come from the National China Statistical Yearbook up to 2004; data for 2005-8 are aggregates from provincial statistics, because this aggregation is not available in the later National Yearbooks. These later data may be less reliable since provincial statistics seem to be subject to 'inflation', as may be seen by comparing the final column total here with the sum of the annual numbers for 2005 to 2008 in Table 1. 